\title{
Ebastine in the Treatment of Allergic Rhinitis and Urticaria: 30 Years of Clinical Studies and Real-World Experience
}

\section{Sastre J}

\begin{abstract}
Department of Allergy, Fundación Jimenez Diaz, Madrid. CIBERES, Instituto Carlos III Department of Medicine, Universidad Autónoma de Madrid, Madrid, Spain
\end{abstract}

J Investig Allergol Clin Immunol 2020; Vol. 30(3): 156-168

doi: 10.18176/jiaci.0401

\begin{abstract}
Histamine, acting predominantly via the $\mathrm{H}_{1}$-receptor, is an important mediator of the symptoms of allergy. $\mathrm{H}_{1}$-antihistamines, which stabilize the receptor in its inactive form, are the treatment of choice for some chronic allergic conditions. Ebastine is a well-established secondgeneration oral $\mathrm{H}_{1}$-antihistamine that is administered once daily at a dose of $10-20 \mathrm{mg}$ and is available both as a standard tablet and as a fast-dissolving tablet that disintegrates in the mouth. Ebastine has been shown to relieve symptoms in patients with allergic rhinitis or urticaria in multiple clinical trials. In addition to its antihistamine effects, the drug has modulating effects on the allergic inflammatory process, thus potentially explaining its beneficial effect on nasal obstruction in some patients. Ebastine is generally well tolerated at recommended doses and is one of the lowest-risk antihistamines with respect to adverse cognitive/psychomotor effects, as confirmed by decades of pharmacovigilance. New long-term data confirm its efficacy and tolerability during up to 1 year of treatment in patients with chronic urticaria.
\end{abstract}

Key words: Allergic rhinitis. Urticaria. Ebastine. Antihistamines. $\mathrm{H}_{1}$-receptor antagonists.

\section{Resumen}

La histamina, que actúa predominantemente a través del receptor $\mathrm{H}_{1}$, es un mediador importante de los síntomas de alergia, y los antihistamínicos $\mathrm{H}_{1}$, que estabilizan el receptor en su forma inactiva, son el tratamiento de elección para algunas afecciones alérgicas crónicas. La ebastina es un antihistamínico $\mathrm{H}_{1}$ oral de segunda generación bien establecido. Se administra una vez al día en una dosis de 10 a 20 mg y está disponible como comprimido estándar y también como comprimido de disolución rápida que se desintegra en la boca. La ebastina ha demostrado en numerosos ensayos clínicos ser eficaz para aliviar los síntomas de pacientes con rinitis alérgica o urticaria. La ebastina tiene efectos moduladores del proceso inflamatorio alérgico además de sus efectos antihistamínicos, lo que pueden ayudar a explicar el efecto beneficioso que tiene sobre la obstrucción nasal en algunos pacientes. La ebastina es generalmente bien tolerada a las dosis recomendadas y es uno de los antihistamínicos de menor riesgo con respecto a los efectos adversos cognitivos/psicomotores, confirmado después de décadas de farmacovigilancia. Los nuevos datos a largo plazo confirman su eficacia y tolerabilidad hasta un año de tratamiento en pacientes con urticaria crónica.

Palabras clave: Rinitis alérgica. Urticaria. Ebastina. Antihistamínicos. Antagonistas del receptor $\mathrm{H}_{1}$. 


\section{Introduction}

Allergic disorders such as allergic rhinitis and urticaria are a common problem worldwide $[1,2]$. The estimated prevalence of confirmed allergic rhinitis in Europe ranges from $17 \%$ to $28.5 \%[1,3]$. The prevalence of the disease is increasing in other countries with previously low-to-medium prevalence, such as China, and elsewhere $[1,4-6]$. The prevalence of urticaria is estimated to be $0.5 \%-5 \%$ [2,7-9]. In a crosssectional population survey, lifetime prevalence for all types of urticaria was estimated to be approximately $9 \%$, and this was considered to be a lower limit because of the conservative prevalence calculations employed [8].

Both allergic rhinitis and urticaria have an adverse impact on quality of life and daily functioning [7,10-14], and allergic rhinitis in particular is associated with a high economic burden for society in terms of work absenteeism and presenteeism $[15,16]$.

Histamine, acting predominantly via the $\mathrm{H}_{1}$-receptor, is an important mediator of the symptoms of allergy [17]. It is released as a preformed mediator from activated mast cells during the early phase of the immune response [18]. $\mathrm{H}_{1}$-antihistamines, which stabilize the receptor in its inactive form, are the treatment of choice for allergic conditions [17] and are included in international guidelines for the management of allergic rhinitis [1,19] and urticaria [20]. Ebastine is a well-established second-generation $\mathrm{H}_{1}$-antihistamine [21] that has been available across Europe and worldwide for almost 30 years. The most recent comprehensive review of ebastine was published 10 years ago [21]. The current review summarizes data on the use of ebastine to treat allergic rhinitis and urticaria and includes new information that has become available in the last decade.

Table 1. Pharmacodynamic Properties of Ebastine

Antihistamine Activity

Ebastine $\geq 10 \mathrm{mg}$ reduced histamine-induced cutaneous wheal response vs placebo in healthy adults and adults with allergic rhinitis $(P<.05)$ [22-29].

After single doses of ebastine 1-30 mg, peak inhibition of wheals occurred 2-12 h after intradermal histamine challenge (dose-dependent effect); after $24 \mathrm{~h}$, wheals remained reduced by $50 \%$ with ebastine $10 \mathrm{mg}$ vs placebo [27,28].

Inhibitory effect of ebastine on wheal/flare responses disappeared by $5 \mathrm{~d}$ after stopping administration [30].

Ebastine $10 \mathrm{mg}$ as effective as cetirizine $10 \mathrm{mg}$, fexofenadine $120 \mathrm{mg}$, loratadine $10 \mathrm{mg}$, and mizolastine $10 \mathrm{mg}$ at inhibiting histamineinduced wheal response [25,29]. Ebastine $20 \mathrm{mg}$ more effective $(P<.05)$ than cetirizine, loratadine, and fexofenadine at $24 \mathrm{~h}$ after dosing $[22,25,26]$. Results for flare response after cutaneous histamine challenge generally consistent with those for wheal response [22,26,31].

Ebastine fast-dissolving tablet $10 \mathrm{mg}$ and $20 \mathrm{mg}$ more effective than desloratadine $5 \mathrm{mg}$ at inhibiting the histamine-induced wheal response at $24 \mathrm{~h}$ after dosing $(P<.001)[23,24]$.

Ebastine 10 and $30 \mathrm{mg}$ reduced histamine-induced bronchoconstriction vs placebo in patients with asthma; no dose-response relationship [32].

Antiallergy Effects

In patients with animal/plant allergies, wheal and flare responses to cutaneous allergen challenge reduced significantly $(P<.01)$ by ebastine $20 \mathrm{mg}$ versus placebo at 6,24 , and $48 \mathrm{~h}$ after completing $1 \mathrm{wk}$ of treatment [30].

In patients with grass pollen allergy, ebastine $10 \mathrm{mg}$ reduced pollen-induced wheal diameter significantly vs placebo $(P=.013)$ and to a similar extent to cetirizine $10 \mathrm{mg}$, fexofenadine $120 \mathrm{mg}$, loratadine $10 \mathrm{mg}$, and mizolastine $10 \mathrm{mg}$ [29]. All antihistamines reduced nasal blockage and sneezing (but not rhinorrhea) vs placebo at $4 \mathrm{~h}$ after nasal provocation with pollen $(P<.05)$ [29].

In patients with grass pollen allergy, mean number of pollen grains needed to induce an allergic response after nasal provocation was higher in recipients of ebastine 10 or $20 \mathrm{mg}$ vs placebo $(P<.05)[33]$.

Effects on Other Mediators of Inflammation

In nasal polyp cells in vitro, ebastine inhibited anti-IgE-induced release of prostaglandin $\mathrm{D}_{2}\left(\mathrm{PGD}_{2}\right)$ and leukotrienes $\mathrm{C}_{4} / \mathrm{D}_{4}\left(\mathrm{LTC} / \mathrm{D}_{4}\right)$ $(P<.05)$. It also inhibited granulocyte-macrophage colony-stimulating factor (GM-CSF), tumour necrosis factor- $\alpha$ and interleukin 8 release [33]. Carebastine had a smaller effect than ebastine.

In patients with grass pollen allergy, ebastine 10 and $20 \mathrm{mg}$ reduced the release of GM-CSF (but not $\mathrm{PGD}_{2}, \mathrm{LTC}_{4} / \mathrm{D}_{4}$ or other cytokines) in nasal secretions in a dose-dependent manner [33].

In patients with grass pollen allergy, a smaller increase in nasal eosinophilia was seen after treatment with ebastine $10 \mathrm{mg}$ vs placebo $(P=.004)$; effect was similar to that seen with cetirizine, fexofenadine, loratadine, and mizolastine [29].

In patients with bronchial asthma, ebastine $10 \mathrm{mg}$ reduced peripheral blood eosinophil count $(P<.0253)$ and serum eosinophil cationic protein level $(P<.0014)$ in atopic but not nonatopic patients [34].

In patients with persistent allergic rhinitis, ebastine increased production of interferon $\gamma$ by peripheral blood mononuclear cells in response to stimulation by grasses $(P<.0001)$ or house dust mite Dermatophagoides farinae $(P=.0015)$ [35].

Ebastine demonstrated potent antiangiogenic activity in in vitro assays (human umbilical vein endothelial cell and human pulmonary artery cell) $(P \leq .03)$ and in an in vivo assay (chick embryo chorioallantoic membrane) $(P<.001)[36]$. 


\section{Pharmacological Properties}

Ebastine is a second-generation $\mathrm{H}_{1}$-antihistamine. It has an oxypiperidine-based structure and is metabolized to carebastine, its active metabolite, after oral administration.

\section{Pharmacodynamic Profile}

Since ebastine was introduced 30 years ago, its pharmacodynamic activity has been extensively demonstrated using cutaneous histamine challenge tests, histamine-induced bronchoconstriction tests, cutaneous and nasal allergen challenge tests, and measurement of inflammatory mediators. The findings are summarized in Table 1 [22-36]. The key points are as follows: ebastine inhibited cutaneous reaction to histamine in a dose-dependent manner; and ebastine $20 \mathrm{mg}$ reduced histamine-induced wheals to a greater extent than cetirizine $10 \mathrm{mg}$, fexofenadine $120 \mathrm{mg}$, and loratadine $10 \mathrm{mg}$. In addition, the quantity of pollen needed to induce a nasal allergic response was greater with ebastine, and the effects of the drug lasted for at least 48 hours (Table 1).

Ebastine also has effects on nonhistamine mediators of inflammation (Table 1). Two relevant studies have been published since the last review [21]. People with allergies are often deficient in interferon $\gamma$, and it has been shown that ebastine increases production of interferon $\gamma$ by peripheral blood mononuclear cells in response to stimulation by grasses $(P<.0001)$ or the house-dust mite Dermatophagoides farinae $(P=.0015)$ in patients with persistent allergic rhinitis [35]. This effect was significantly associated with an improvement in allergy symptoms, as measured by the total nasal symptom score $(P=.0038)$ and patient-reported overall symptoms in a visual analog scale $(P=.004)$. Angiogenesis, which is associated with increased expression of vascular endothelial growth factor (VEGF), is implicated in airway inflammation and remodelling in allergic rhinitis and asthma, and ebastine was found to have potent antiangiogenic activity in in vitro and in vivo assays [36]. Carebastine, the active metabolite of ebastine, inhibited the VEGF-induced angiogenic response in a chick embryo chorioallantoic membrane assay $(P<.001)$, with the effect mediated predominantly by an $\mathrm{H}_{1}$-receptordependent mechanism and, albeit to a lesser extent, by an $\mathrm{H}_{1}$-receptor-independent mechanism [36].

\section{Pharmacokinetic Profile}

The pharmacokinetic profile of ebastine/carebastine is summarized in Table 2 [21,28,37-52]. Ebastine is

Table 2. Pharmacokinetic Properties of Carebastine [21,28,37-52 $]^{\mathrm{a}}$

\begin{tabular}{|c|c|}
\hline Parameter & Finding \\
\hline Maximum plasma concentration & $\begin{array}{l}\text { Single dose: } 10 \mathrm{mg}, 80-115 \mathrm{ng} / \mathrm{mL} ; 20 \mathrm{mg}, 157-243 \mathrm{ng} / \mathrm{mL} \\
\text { Multiple doses: } 10 \mathrm{mg}, 130-162 \mathrm{ng} / \mathrm{mL} ; 20 \mathrm{mg}, 273-396 \mathrm{ng} / \mathrm{mL}\end{array}$ \\
\hline Time to maximum plasma concentration & $\begin{array}{l}\text { Single dose: } 10 \mathrm{mg}, 2.6-5.7 \mathrm{~h} ; 20 \mathrm{mg}, 1-5 \mathrm{~h} \\
\text { Multiple doses: } 10 \mathrm{mg}, 5.1 \mathrm{~h} ; 20 \mathrm{mg}, 4.5-5 \mathrm{~h}\end{array}$ \\
\hline $\begin{array}{l}\text { Area under the plasma-concentration } \\
\text { time curve }\end{array}$ & $\begin{array}{l}\text { Single dose: } 10 \mathrm{mg}, 1755-3189 \mathrm{ng} / \mathrm{mL} / \mathrm{h} ; 20 \mathrm{mg}, 5721 \mathrm{ng} / \mathrm{mL} / \mathrm{h} \\
\text { Multiple doses: } 10 \mathrm{mg}, 2742 \mathrm{ng} / \mathrm{mL} / \mathrm{h} ; 20 \mathrm{mg}, 4200-5608 \mathrm{ng} / \mathrm{mL} / \mathrm{h}\end{array}$ \\
\hline Time to steady-state concentration & Approximately 4 days \\
\hline Effect of food & Ebastine can be administered with or without food \\
\hline Plasma protein binding & $>95 \%$ \\
\hline Apparent volume of distribution & 90-143 L (single $10 \mathrm{mg}$ dose) \\
\hline Metabolism & Via cytochrome P450 enzymes, including CYP3A4, CYP2J2, CYP4F \\
\hline Urinary excretion & Accounts for $66 \%$ of administered dosage; mainly in form of conjugated metabolites \\
\hline Clearance & $4.8 \mathrm{~L} / \mathrm{h}$ (single $10 \mathrm{mg}$ dose) \\
\hline Elimination half-life & $\begin{array}{l}\text { Single dose: } 10 \mathrm{mg}, 10.3-19 \mathrm{~h} ; 20 \mathrm{mg}, 15 \mathrm{~h} \\
\text { Multiple doses: } 10 \mathrm{mg}, 19 \mathrm{~h} ; 20 \mathrm{mg}, 15-24.5 \mathrm{~h}\end{array}$ \\
\hline Effect of age and gender & $\begin{array}{l}\text { Age has no clinically relevant effect on carebastine pharmacokinetics, and dose } \\
\text { modifications are not needed in elderly patients }\end{array}$ \\
\hline Hepatic and renal impairment & $\begin{array}{l}\text { Hepatic and renal impairment have no clinically relevant effect on carebastine } \\
\text { pharmacokinetics. No dose adjustment needed for renal impairment or for mild or } \\
\text { moderate hepatic impairment. Maximum dose in severe hepatic impairment is } 10 \mathrm{mg} \text {, } \\
\text { as this was the highest dose evaluated in this subgroup }\end{array}$ \\
\hline Drug interactions & $\begin{array}{l}\text { Pharmacokinetic interaction with drugs metabolized by CYP3A4, eg, coadministration } \\
\text { with ketoconazole, itraconazole or erythromycin leads to increased plasma concentrations } \\
\text { of ebastine/carebastine } \\
\text { Pharmacokinetic interaction with rifampin (rifampicin), leading to reduced plasma } \\
\text { concentration of carebastine } \\
\text { No significant interactions with cimetidine, diazepam, or alcohol }\end{array}$ \\
\hline
\end{tabular}

\footnotetext{
aSpecific values are for adults taking the standard tablet formulation of ebastine.
} 
Table 3. Randomized, Double-Blind, Controlled Trials Evaluating the Efficacy of Ebastine in Adults and Adolescents With Seasonal Allergic Rhinitis ${ }^{\mathrm{a}}$

\begin{tabular}{|c|c|c|c|}
\hline $\begin{array}{l}\text { Clinical Trial } \\
\text { (Duration) }\end{array}$ & No. & Treatment & Results \\
\hline [54] (4 wk) & 40 & $\begin{array}{l}\text { Ebastine } 10-40 \mathrm{mg} \\
\text { (titrated) } \\
\text { Placebo }\end{array}$ & $\begin{array}{l}\text { Ebastine more efficacious than placebo for relief of nasal symptoms }(P<.05) \text { but not } \\
\text { ocular symptoms. } \\
\text { Global efficacy rated good/very good by more patients and physicians for } \\
\text { ebastine than placebo (patients } 84 \% \text { vs } 40 \% \text {; physicians: } 79 \% \text { vs } 35 \% \text {; overall } P<.01 \text { ). }\end{array}$ \\
\hline$[55](2 \mathrm{wk})$ & 116 & $\begin{array}{l}\text { Ebastine } 10 \mathrm{mg} \\
\text { Placebo }\end{array}$ & $\begin{array}{l}\text { Ebastine } 10 \mathrm{mg} \text { more efficacious than placebo for relief of nasal symptoms such as } \\
\text { rhinorrhoea }(P=.003) \text { and sneezing }(P=.008) \text { (but not nasal obstruction) and ocular } \\
\text { symptoms such as tears and conjunctival irritation ( } P \text { values not reported). } \\
\text { Ebastine } 10 \mathrm{mg} \text { more efficacious than placebo based on physician global efficacy rating } \\
\text { of good/excellent ( } 56 \% \text { vs } 46 \%, P=.008) \text {. }\end{array}$ \\
\hline [56] (1 wk) & 201 & $\begin{array}{l}\text { Ebastine } 10 \mathrm{mg} \\
\text { Ebastine } 20 \mathrm{mg} \\
\text { Placebo }\end{array}$ & $\begin{array}{l}\text { Ebastine } 10 \text { and } 20 \mathrm{mg} \text { more efficacious }(P<.05) \text { than placebo for relief of nasal symptoms } \\
\text { (except obstruction) and ocular symptoms (except watering eyes with ebastine } 20 \mathrm{mg}) \text {. } \\
\text { Ebastine } 10 \text { and } 20 \mathrm{mg} \text { more efficacious than placebo based on patient }(P<.05) \text { and } \\
\text { physician }(P<.01) \text { global efficacy rating. More patients and physicians rated ebastine } \\
10 \text { and } 20 \mathrm{mg} \text { as "efficacious" (i.e. moderate/ good/excellent) than rated placebo as } \\
\text { such (patients } 61 \% \text { vs } 66 \% \text { vs placebo } 36 \% \text {; physicians: } 72 \% \text { vs } 64 \% \text { vs placebo } 33 \% \text { ). } \\
\text { No significant differences between ebastine } 10 \text { and } 20 \mathrm{mg} \text {. }\end{array}$ \\
\hline [57] (3 wk) & 396 & $\begin{array}{l}\text { Ebastine } 10 \mathrm{mg}(\mathrm{am}) \\
\text { Ebastine } 10 \mathrm{mg}(\mathrm{pm}) \\
\text { Ebastine } 20 \mathrm{mg}(\mathrm{am}) \\
\text { Ebastine } 20 \mathrm{mg}(\mathrm{pm}) \\
\text { Placebo }\end{array}$ & $\begin{array}{l}\text { Ebastine } 10 \mathrm{mg}(\mathrm{am}) \text { and } 20 \mathrm{mg}(\mathrm{am} \text { or } \mathrm{pm}) \text { - but not } 10 \mathrm{mg}(\mathrm{pm}) \text { - more efficacious than } \\
\text { placebo at improving total symptom score and relieving individual nasal and ocular } \\
\text { symptoms }(P<.05) \text {. Mean change from baseline in total symptom score was }-3.5 \mathrm{and} \\
-3.2 \mathrm{for} \text { ebastine } 10 \mathrm{mg}(\mathrm{am}) \text { and } 10 \mathrm{mg}(\mathrm{pm}) \mathrm{vs}-4.0 \text { and }-3.6 \text { for ebastine } 20 \mathrm{mg}(\mathrm{am}) \\
\text { and } 20 \mathrm{mg}(\mathrm{pm}) \mathrm{vs}-2.7 \text { for placebo (estimated from graph). } \\
\text { Ebastine } 20 \mathrm{mg}(\mathrm{am} \text { and pm)-but not ebastine } 10 \mathrm{mg}(\mathrm{am} \text { or pm) - better than } \\
\text { placebo based on patient global efficacy rating }(P<.05) \text {. } \\
\text { Efficacy was maintained during a 4-month extension period. }\end{array}$ \\
\hline [58] (2 wk) & 343 & $\begin{array}{l}\text { Ebastine } 10 \mathrm{mg} \\
\text { Ebastine } 20 \mathrm{mg} \\
\text { Cetirizine } 10 \mathrm{mg}\end{array}$ & $\begin{array}{l}\text { No significant difference in change in total symptom score between groups at study } \\
\text { end. Greater reduction in total symptom score with ebastine } 20 \mathrm{mg} \text { vs ebastine } 10 \mathrm{mg} \\
\text { and cetirizine } 10 \mathrm{mg} \text { after } 1 \text { week }(P<.05) \text {. In a subgroup with more severe baseline } \\
\text { symptoms ( }=158) \text {, greater reduction in total symptom score at study end with ebastine } \\
20 \mathrm{mg} \text { vs ebastine } 10 \mathrm{mg}(P=.027) \text { but not vs cetirizine } 10 \mathrm{mg} \text {. } \\
\text { Physician (but not patient) global efficacy ratings better for ebastine } 20 \mathrm{mg} \text { (but not } \\
10 \mathrm{mg} \text { ) vs cetirizine } 10 \mathrm{mg} \text { (improvement in } 85 \% \text { vs } 73 \% ; P=.048) \text {. }\end{array}$ \\
\hline [59] (4 wk) & 749 & $\begin{array}{l}\text { Ebastine } 10 \mathrm{mg} \\
\text { Ebastine } 20 \mathrm{mg} \\
\text { Loratadine } 10 \mathrm{mg} \\
\text { Placebo }\end{array}$ & $\begin{array}{l}\text { Ebastine } 10 \text { and } 20 \mathrm{mg} \text { more efficacious than placebo for all composite scores }(P<.01) \text {. } \\
\text { Patient and physician global ratings not significantly different vs placebo for any active treatment. } \\
\text { Reductions in reflective nasal index scores with/without congestion (but not in reflective } \\
\text { total symptom score with/without congestion) and in all four snapshot composite scores } \\
\text { were greater with ebastine } 20 \mathrm{mg} \text { vs loratadine } 10 \mathrm{mg}(P<.05) \text {. No significant differences } \\
\text { between ebastine } 10 \mathrm{mg} \text { vs loratadine } 10 \mathrm{mg} \text { for any composite scores. } \\
\text { No significant difference for ebastine } 10 \text { or } 20 \mathrm{mg} \text { vs loratadine for patient or physician } \\
\text { global ratings. }\end{array}$ \\
\hline [60] (4 wk) & 565 & $\begin{array}{l}\text { Ebastine } 10 \mathrm{mg} \\
\text { Ebastine } 20 \mathrm{mg} \\
\text { Loratadine } 10 \mathrm{mg} \\
\text { Placebo }\end{array}$ & $\begin{array}{l}\text { Ebastine } 10 \text { and } 20 \mathrm{mg} \text { more efficacious than placebo for all composite scores }(P<.05) \text {; } \\
\text { loratadine better than placebo for all composite scores except snapshot total symptom } \\
\text { score and nasal index. } \\
\text { Patient and physician global ratings better with all active treatments vs placebo }(P<.05) \text {. } \\
\text { Greater reduction in all four mean daily reflective composite scores (total symptom } \\
\text { score with/without congestion and nasal index with/without congestion), all } 4 \text { morning } \\
\text { snapshot composite scores and most individual scores with ebastine } 20 \mathrm{mg} \text { vs loratadine } \\
10 \mathrm{mg}(P<.05) \text {. No significant difference between ebastine } 10 \mathrm{mg} \text { vs loratadine } 10 \mathrm{mg} \text {. } \\
\text { Patient and physician global ratings did not differ significantly between active treatments. }\end{array}$ \\
\hline [61] (2 wk) & 703 & $\begin{array}{l}\text { Ebastine } 20 \mathrm{mg} \\
\text { Loratadine } 10 \mathrm{mg} \\
\text { Placebo }\end{array}$ & $\begin{array}{l}\text { Greater reductions in all mean daily reflective and snapshot composite scores (total symptom } \\
\text { score, nasal index) and individual nasal and ocular scores (except for snapshot nasal congestion) } \\
\text { with ebastine } 20 \mathrm{mg} \text { vs placebo }(P<.05) \text {, but not for loratadine } 10 \mathrm{mg} \text { vs placebo. } \\
\text { Greater reduction in all mean daily reflective and snapshot composite and individual } \\
\text { nasal and ocular scores with ebastine } 20 \mathrm{mg} \text { vs loratadine } 10 \mathrm{mg}(P<.05) \text {. Change in } \\
\text { mean daily reflective total symptom score }-3.46(-32.3 \%) \text { with ebastine } 20 \mathrm{mg} \text { vs }-2.77 \\
(-24.6 \%) \text { with loratadine } 10 \mathrm{mg}(P=.0018) \text {. } \\
\text { Patient and physician global ratings did not differ significantly between ebastine and loratadine. }\end{array}$ \\
\hline
\end{tabular}

aEfficacy was generally based on evaluation of nasal symptoms (rhinorrhea, sneezing, itching, obstruction) and ocular symptoms (itching, discharge, conjunctivitis). Symptoms were assessed individually and/or as composite scores, such as total symptom score, nasal index (composite of 4 nasal symptoms) or perennial index (nasal symptoms excluding obstruction). Symptoms were usually rated on a graded scale ( $0=$ absent, $1=$ mild, $2=$ moderate, $3=$ severe). In some trials, patients recorded symptom scores twice daily, based on their symptoms over the previous 12 hours (reflective score) and at the time of recording (snapshot score). 
Table 4. Randomized, Double-Blind, Controlled Trials Evaluating the Efficacy of Ebastine in Adults and Adolescents With Perennial Allergic Rhinitis ${ }^{\mathrm{a}}$

\begin{tabular}{|c|c|c|c|}
\hline $\begin{array}{l}\text { Clinical Trial } \\
\text { (Duration) }\end{array}$ & No. & Treatment & Results \\
\hline 5 [62] (1 wk) & 151 & $\begin{array}{l}\text { Ebastine } 10 \mathrm{mg} \\
\text { Placebo }\end{array}$ & $\begin{array}{l}\text { Ebastine } 10 \mathrm{mg} \text { more efficacious than placebo for relief of all nasal symptoms } \\
\text { (except obstruction) and ocular symptoms }(P<.05) \text {. } \\
\text { Efficacy rated as excellent/good/moderate by more patients and physicians for ebastine } \\
10 \mathrm{mg} \text { than placebo }(54 \%-55 \% \text { vs } 31 \%-32 \% ; P<.01) \text {. }\end{array}$ \\
\hline [63] (12 wk) & 290 & $\begin{array}{l}\text { Ebastine } 10 \mathrm{mg} \\
\text { Ebastine } 20 \mathrm{mg} \\
\text { Placebo }\end{array}$ & $\begin{array}{l}\text { Ebastine } 20 \mathrm{mg} \text { more efficacious than placebo for reduction from baseline in mean daily } \\
\text { perennial index }(-1.9[-39 \%] \text { vs }-1.2[-26 \%], P=.006 \text {; estimated from graph), morning } \\
\text { perennial index }(P=.007) \text { and mean daily nasal index }(P=.015) \text {. Ebastine } 10 \mathrm{mg} \text { more } \\
\text { effective than placebo for reduction in morning perennial index }(P=.047) \text {. } \\
\text { More patients and physicians rated condition as somewhat/greatly improved with ebastine } \\
10 \mathrm{mg}(72 \%-80 \%) \text { and } 20 \mathrm{mg}(84 \%) \text { than with placebo }(58 \%)(P<.02) \text {. } \\
\text { No significant differences between ebastine } 10 \text { and } 20 \mathrm{mg} \text {. }\end{array}$ \\
\hline [64] (4 wk) & 214 & $\begin{array}{l}\text { Ebastine } 10 \mathrm{mg} \\
\text { Cetirizine } 10 \mathrm{mg}\end{array}$ & $\begin{array}{l}\text { No significant difference between ebastine } 10 \mathrm{mg} \text { and cetirizine } 10 \mathrm{mg} \text { for mean } \\
\text { percentage change in nasal index at study end. Greater mean percentage change in nasal } \\
\text { index with cetirizine } 10 \mathrm{mg} \text { after } 1 \text { week }(P<.04) \text {. } \\
\text { More cetirizine recipients had reduced nasal congestion }(P<.04) \text { and were symptom-free } \\
(P=.02) \text { at study end. }\end{array}$ \\
\hline [65] (4 wk) & 317 & $\begin{array}{l}\text { Ebastine } 10 \mathrm{mg} \\
\text { Ebastine } 20 \mathrm{mg} \\
\text { Loratadine } 10 \mathrm{mg}\end{array}$ & $\begin{array}{l}\text { Ebastine } 10 \text { and } 20 \mathrm{mg} \text { more efficacious than loratadine } 10 \mathrm{mg} \text { at reducing perennial } \\
\text { index, nasal index, nasal discharge, and nasal congestion }(P<.05) \text {. No significant } \\
\text { differences between ebastine doses. } \\
\text { Condition rated as improved by more patients and physicians for ebastine } 10 \text { and } 20 \mathrm{mg} \\
(79 \%-85 \%) \text { vs loratadine } 10 \mathrm{mg}(65 \%-66 \%)(P<.05) .\end{array}$ \\
\hline
\end{tabular}

aEfficacy was generally based on evaluation of nasal symptoms (rhinorrhea, sneezing, itching, obstruction) and ocular symptoms (itching, discharge, conjunctivitis). Symptoms were assessed individually and/or as composite scores, such as total symptom score, nasal index (composite of four nasal symptoms) or perennial index (nasal symptoms excluding obstruction). Symptoms were usually rated on a graded scale $(0=$ absent, $1=$ mild, $2=$ moderate, $3=$ severe). In some trials, patients recorded symptom scores twice daily, based on their symptoms over the previous 12 hours (reflective score) and at the time of recording (snapshot score).

administered once daily. After oral administration, ebastine undergoes rapid and extensive first-pass metabolism to carebastine, its active metabolite $[28,48]$. Carebastine exhibits dose-dependent pharmacokinetics [28,48]. Peak plasma concentrations of carebastine are reached at 4-6 hours after dosing, and steady-state levels are achieved within 4 days (Table 2). Pharmacokinetic bioequivalence between the fastdissolving tablet formulation of ebastine (which disintegrates in the mouth) and the standard tablet formulation (which is swallowed) has been established [53].

Coadministration with drugs metabolized by CYP3A4, such as ketoconazole and erythromycin, leads to increased plasma concentrations of ebastine/carebastine [37]. Since the previous review, a pharmacokinetic interaction between rifampicin (rifampin) and ebastine has been reported: coadministration led to reduced oral bioavailability of ebastine, with a $15 \%$ decrease in the area under the plasma concentration time curve for carebastine $(P<.001)$ [49].

\section{Clinical Efficacy}

Once-daily oral ebastine is indicated for the symptomatic treatment of allergic rhinitis/rhinoconjunctivitis (adults and adolescents aged $\geq 12$ years) and urticaria (adults).

\section{Allergic Rhinitis}

Most clinical trials of ebastine in allergic rhinitis were conducted prior to the introduction of the ARIA classification based on intermittent or persistent symptoms and therefore used the earlier terminology of seasonal and perennial allergic rhinitis. Studies generally enrolled adults and adolescents aged $\geq 12$ years, and allergic rhinitis was usually diagnosed based on the clinical history and a positive skin prick test or IgE test result. The most common primary efficacy parameter was the change from baseline in total symptom score; however, some studies used a global evaluation of symptomatic improvement/ efficacy by the physician or patient.

The results of controlled trials of ebastine in adults/ adolescents with seasonal allergic rhinitis or perennial allergic rhinitis are summarized in Tables 3 [54-61] and 4 [62-65], respectively. Ebastine was significantly more effective than placebo at relieving the symptoms of seasonal and perennial allergic rhinitis [54-57,58-63].

The results of comparisons with other antihistamines indicate that ebastine $10 \mathrm{mg}$ was at least as effective as cetirizine $10 \mathrm{mg}$ and loratadine $10 \mathrm{mg}$ at relieving the symptoms of allergic rhinitis and that ebastine $20 \mathrm{mg}$ was generally more effective than loratadine $10 \mathrm{mg}$ [58-61,64,65]. A meta-analysis of 4 studies on seasonal allergic rhinitis confirmed that ebastine $20 \mathrm{mg}$ was superior to loratadine $10 \mathrm{mg}$, as indicated by the mean change from baseline in the overall mean daily reflective total symptom score during the first 2 weeks of treatment $(-3.61[-35.4 \%]$ vs $-3.05[-29.0 \%]$, $P<.001)$ [66].

Whereas most nasal symptoms are due primarily to the effect of histamine, nasal obstruction is associated with multiple chemical mediators [67-69], and oral $\mathrm{H}_{1}$-antihistamines tend 
to be less effective for nasal congestion than for other nasal symptoms [1]. Three studies that evaluated mean change from baseline in reflective and snapshot nasal congestion symptom scores (total of 6 scores across the 3 studies) found that ebastine $20 \mathrm{mg}$ was more efficacious than placebo for 6 of 6 scores and ebastine $10 \mathrm{mg}$ for 4 of 6 scores, whereas loratadine $10 \mathrm{mg}$ was more efficacious than placebo for only 1 of 6 scores [70]. A small noncomparative study in patients with persistent allergic rhinitis $(n=20)$ that specifically evaluated nasal symptoms found that ebastine $20 \mathrm{mg}$ significantly improved rhinomanometry-assessed nasal airflow by $59 \%$ from baseline $(P=.0001)$ and modified the response to the nasal decongestion test $(P=.0003)[71]$.

\section{Patient Acceptance and Satisfaction}

It is important that therapies for allergic rhinitis are acceptable to patients to ensure that they adhere to longterm treatments in the real-world setting. Studies evaluating patients' perception of the fast-dissolving tablet formulation of ebastine and their willingness to use it have been reviewed in detail $[21,72]$. Patients generally preferred the taste and texture of the fast-dissolving tablet over the standard ebastine tablet [73]: they found it convenient and easy to use, perceived it to have a fast onset of action, and reported high levels of satisfaction [73-76]. Most expressed a preference for it over their previous antihistamine treatment [74-76].

One of the patient preference studies, which was available only as a conference abstract for the last full review of ebastine, has since been published in full [76]. This international observational study of patients who had been

A

a. Pruritus ( $P=.0001$ baseline to 6 months)
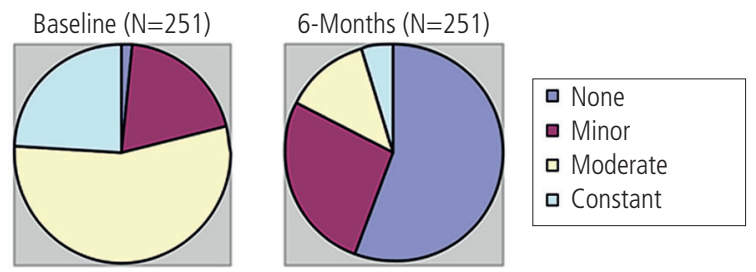

b. Number of wheals ( $P=.0001$ baseline to 6 months)

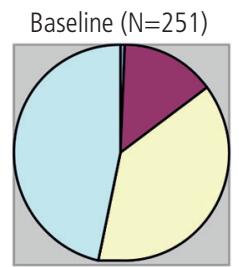

6-Months ( $\mathrm{N}=251)$

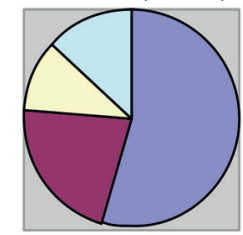

\section{ㅁ 0}

1 to 5

6 to 15

16 or more

c. Size of wheals ( $P=.0001$ baseline to 6 months)

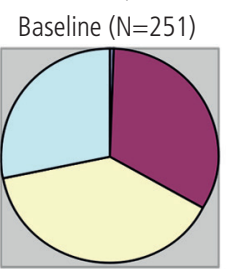

6-Months ( $N=251)$

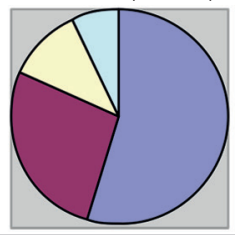

$\square 0 \mathrm{~mm}$

- $1-10 \mathrm{~mm}$

11-29mm

口 $30 \mathrm{~mm}$ or more

prescribed the ebastine fast-dissolving tablet $20 \mathrm{mg}$ within the previous 2 months $(\mathrm{n}=461)$ used the Treatment Satisfaction Questionnaire for Medication (TSQM). The authors found that patients rated the ebastine tablet highly for effectiveness (TSQM score 74.2 out of a maximum 100), adverse effects (95.3), convenience (87.9), and global satisfaction (78.6) [76]. Compared with their previous antihistamine therapy, the ebastine fast-dissolving 20-mg tablet was rated better/much better by $81 \%$ of patients in terms of effectiveness, by $73 \%$ for tolerability, $79 \%$ for onset of action, and $94 \%$ for convenience. Overall, $94 \%$ of patients indicated they would like to continue using the ebastine fast-dissolving tablet [76].

\section{Urticaria}

The efficacy of ebastine in the treatment of chronic urticaria was evaluated in adult patients. Ebastine was assessed in patients with chronic idiopathic urticaria (which would now be designated chronic spontaneous urticaria) in 2 randomized, double-blind, placebo-controlled trials [77,78], 1 of which also included a comparison with terfenadine [78]. Ebastine $10 \mathrm{mg}$ was significantly more efficacious than placebo at reducing the symptoms of urticaria and showed similar efficacy to terfenadine (Table 5) [9,77-84]. More recently, a randomized trial with the primary aim of evaluating a method for predicting response to treatment in patients with chronic spontaneous urticaria $(n=213)$ reported that all antihistamines evaluated (ebastine, bilastine, cetirizine, desloratadine, fexofenadine) provided similar efficacy in terms of symptom relief (assessed using the Urticaria Activity Score) and quality of life (Dermatology Life Quality Index) over 8 weeks of treatment (Table 5) [9].

B

a. Pruritus ( $P=.0001$ baseline to 12 months)
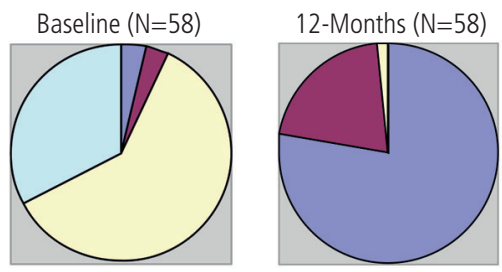

$\square$ None

- Minor

$\square$ Moderate

$\square$ Severe

b. Number of wheals ( $P=.0001$ baseline to 12 months)

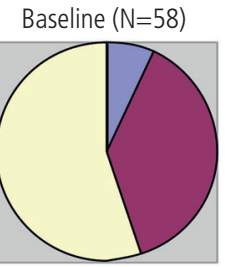

12-Months ( $\mathrm{N}=58$ )

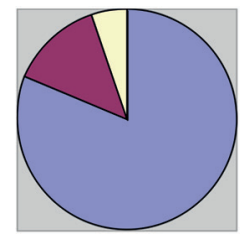

\section{$\square 0$}

- 1 to 5

ㅁ 6 to 15

16 or more

c. Size of wheals ( $P=.0001$ baseline to 12 months)

Baseline $(\mathrm{N}=58)$

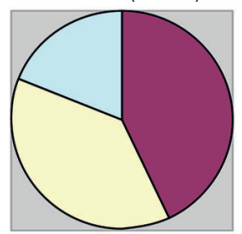

12-Months ( $N=58)$

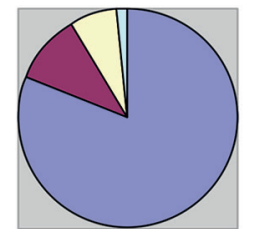

$\square 0 \mathrm{~mm}$

- $1-10 \mathrm{~mm}$

11-29mm

口 $30 \mathrm{~mm}$ or more

Figure. Long-term efficacy (A, 6 months; $B, 12$ months) of ebastine in patients with chronic urticaria: $a$, pruritus; $b$, number of wheals; and c, size of wheals [80]. 
In addition, efficacy data from 2 previously unpublished, long-term, open-label studies of the safety and efficacy of ebastine in patients with chronic urticaria have been reported $[80,81]$. The studies were both multicenter, openlabel, noncomparative studies involving adults with chronic urticaria. Efficacy was evaluated through assessments of symptoms, including pruritus and number and size of wheals, and patient and physician global evaluations. Both studies confirmed the long-term efficacy of ebastine $10 \mathrm{mg}$ in this patient population.

In the first, 251 adults with chronic urticaria from 11 centers in Spain were enrolled in a 6-month, open-label study evaluating the long-term safety and tolerability of ebastine $10 \mathrm{mg}$, in which efficacy was assessed as a secondary objective [80]. The primary evaluation was performed at 6 months. However, a subgroup of patients $(n=58)$ continued

Table 5. Clinical Trials Evaluating the Efficacy of Ebastine in Adults With Urticaria

\begin{tabular}{|c|c|c|c|}
\hline $\begin{array}{l}\text { Clinical Trial } \\
\text { (Duration) }\end{array}$ & No. & Treatment & Results \\
\hline \multicolumn{4}{|c|}{ Randomized Controlled Clinical Trials in Chronic Spontaneous Urticaria } \\
\hline [77] (2 wk) & 204 & $\begin{array}{l}\text { Ebastine } 10 \mathrm{mg} \\
\text { Placebo }\end{array}$ & $\begin{array}{l}\text { Ebastine } 10 \mathrm{mg} \text { reduced itching and number and size of wheals vs placebo (all } P<.001) \text {. } \\
\text { Global efficacy rated by patients and physicians as moderate/good for more ebastine } \\
\text { recipients than placebo recipients }(80 \%-83 \% \text { vs } 51-55 \%, P<.001) \text {. }\end{array}$ \\
\hline [78] (12 wk) & 211 & $\begin{array}{l}\text { Ebastine } 10 \mathrm{mg} \\
\text { Terfenadine } 120 \mathrm{mg}^{\mathrm{a}} \\
\text { Placebo }\end{array}$ & $\begin{array}{l}\text { Both ebastine } 10 \mathrm{mg} \text { and terfenadine } 120 \mathrm{mg} \text { were more efficacious }(P<.05) \text { than } \\
\text { placebo at reducing severity of itch and number of wheals and lesions as assessed by } \\
\text { patients (but not physicians). Ebastine was more efficacious than placebo based on } \\
\text { patient/physician global ratings of improvement }(73 \%-75 \% \text { vs } 51 \%-52 \%, P \leq .004) \text {. No } \\
\text { significant differences were found between ebastine and terfenadine for relief of } \\
\text { symptoms, or for global patient/physician ratings. }\end{array}$ \\
\hline [9] $(8 \mathrm{wk})$ & 180 & $\begin{array}{l}\text { Ebastine } 20 \mathrm{mg} \\
\text { Bilastine } 20 \mathrm{mg} \\
\text { Cetirizine } 20 \mathrm{mg} \\
\text { Desloratadine } 5 \mathrm{mg} \\
\text { Fexofenadine } 180 \mathrm{mg} \\
\text { No treatment }\end{array}$ & $\begin{array}{l}\text { 24-h after administration of antihistamine, inhibition of the histamine wheal by }>75 \% \\
\text { was significantly associated with better urticaria activity and dermatology life quality } \\
\text { index (DLQI) scores. The safety and efficacy of the } 5 \text { antihistamines were similar. } \\
\text { After updosing, rates of disease control (DLQI score }<5 \text { ) increased from } 59 \% \text { to } 77 \% \\
\text { with no differences between treatments. }\end{array}$ \\
\hline
\end{tabular}

Open-Label Clinical Trials in Chronic Urticaria/Chronic Spontaneous Urticaria

[79] (4 wk) $30 \quad$ Ebastine 10-40 mg Ebastine was safe and effective at higher doses in patients with chronic spontaneous urticaria, with 17, 8 and 2 patients becoming symptom-free when administered doses of 10, 20, and $40 \mathrm{mg}$, respectively.

[80] 251/58 Ebastine $10 \mathrm{mg}$

$(6 \mathrm{mo}+6 \mathrm{mo}$

follow-up in a

subgroup

of patients)

[81] (12 mo) $192 \quad$ Ebastine $10 \mathrm{mg}$

The percentage of patients with constant pruritus decreased from

$23.9 \%$ at baseline to $4.8 \%$ after 6 months, while the percentage who had $\geq 16$ wheals decreased from $47 \%$ to $13.2 \%$ and the percentage who had wheals $\geq 30 \mathrm{~mm}$ in size decreased from $28.7 \%$ to $7.2 \%$ (all $P=.0001$ ). At 6 months, more than $70 \%$ of patients and physicians rated the overall efficacy of ebastine as optimum or good. Significant differences $(P=.0001)$ were also seen in all symptoms in the subgroup of patients $(\mathrm{n}=58)$ that followed 1 year of treatment.

Over 12 months there was clear improvement in symptoms, including itching, time with symptoms, and wheal number/size. The percentage of patients with severe itching decreased from $22 \%$ at baseline to $<1 \%$ at 12 months, time with symptoms of urticaria decreased from 38 to 6 hours/week, the percentage of patients with wheals $\geq 30 \mathrm{~mm}$ decreased from $15 \%$ to $3 \%$, and the percentage of patients with $\geq 16$ wheals decreased from $27 \%$ to $6 \%$. The overall evaluation of efficacy indicated that approximately $65 \%$ of patients and physicians considered there had been a major improvement in symptoms.

Longitudinal Study in Acute Urticaria

\begin{tabular}{llll}
\hline [82] (4 wk) 150 & $\begin{array}{l}\text { Ebastine } 20 \mathrm{mg} \\
\text { Ebastine } 10 \mathrm{mg} \\
\text { Levocetirizine } 5 \mathrm{mg}\end{array}$ & $\begin{array}{l}\text { After } 4 \text { weeks the mean urticaria activity score was } 1.08 \text { for ebastine } 20 \mathrm{mg}, 1.98 \\
\text { for levocetirizine and } 3.98 \text { for ebastine } 10 \mathrm{mg} \text {. in these } 3 \text { groups the percentage of patients } \\
\text { with symptom relief were } 80 \%, 70 \% \text {, and } 50 \% \text {, respectively. }\end{array}$
\end{tabular}

Double-Blind Crossover Study in Dermographic Urticaria: Pilot Study

[83] $\quad 7 \quad$ Ebastine $20 \mathrm{mg} \quad$ Ebastine prevented signs and symptoms of urticaria resulting from mechanical challenge. (Single-dose) Placebo Of 7 patients with dermographic urticaria, all continued to experience wheals with placebo, but only 2 had wheals after ebastine.

Double-Blind Crossover Study in Acquired Cold Urticaria: Pilot Study

[84] 22 Ebastine $20 \mathrm{mg} \quad$ Ebastine was significantly superior to placebo in terms of reducing the number of patients (Single-dose) Placebo with wheals $(P<.001)$, pruritus $(P<.001)$, and experiencing a burning sensation $(P<.05)$.

Terfenadine administered as $60 \mathrm{mg}$ twice daily. Terfenadine is no longer marketed. 
Table 6. Long-Term Efficacy of Ebastine in Patients With Chronic Urticaria: Results From a 12-Month Noncomparative Evaluation of the Safety and Tolerability of Ebastine $10 \mathrm{mg}$ in Europe [81]

\begin{tabular}{|c|c|c|c|}
\hline \multirow[t]{2}{*}{ Parameter } & \multicolumn{3}{|c|}{$\begin{array}{c}\text { Percentage of Patients } \\
\text { (Unless Otherwise Indicated) }\end{array}$} \\
\hline & Baseline & 6 months & 12 months \\
\hline Pruritus $^{\mathrm{b}}$ & $\mathrm{N}=192$ & $\mathrm{~N}=134$ & $\mathrm{~N}=104$ \\
\hline None & 2.6 & 50.8 & 59.6 \\
\hline Minor & 27.6 & 41.8 & 34.6 \\
\hline Moderate & 47.4 & 6.7 & 4.8 \\
\hline Severe & 22.4 & 0.8 & 1.0 \\
\hline Mean no. of hours with & $\mathrm{N}=190$ & $\mathrm{~N}=129$ & $\mathrm{~N}=103$ \\
\hline symptoms/wk & $37.8 \mathrm{~h}$ & $10.9 \mathrm{~h}$ & $5.8 \mathrm{~h}$ \\
\hline No. of wheals ${ }^{\mathrm{c}}$ & $\mathrm{N}=192$ & $\mathrm{~N}=134$ & $\mathrm{~N}=107$ \\
\hline 0 & 30.7 & 79.1 & 81.3 \\
\hline $1-5$ & 21.9 & 6.7 & 10.3 \\
\hline $6-15$ & 20.3 & 7.5 & 1.9 \\
\hline$\geq 16$ & 27.1 & 5.2 & 5.6 \\
\hline Not assessed & 0.0 & 1.5 & 0.9 \\
\hline Size of wheals ${ }^{\mathrm{c}}$ & $\mathrm{N}=192$ & $\mathrm{~N}=134$ & $\mathrm{~N}=107$ \\
\hline None & 30.7 & 79.1 & 81.3 \\
\hline $1-10 \mathrm{~mm}$ & 26.6 & 7.5 & 11.2 \\
\hline $11-29 \mathrm{~mm}$ & 28.1 & 9.7 & 3.7 \\
\hline$\geq 30 \mathrm{~mm}$ & 14.6 & 2.2 & 2.8 \\
\hline Not assessed & 0.0 & 1.5 & 0.9 \\
\hline \multicolumn{4}{|c|}{$\begin{array}{l}\text { Physician's global evaluation } \\
\text { of efficacy }\end{array}$} \\
\hline Major improvement & - & - & 65.1 \\
\hline Minor improvement & - & - & 20.1 \\
\hline No change or worse & - & - & 11.6 \\
\hline Not done/not applicable & - & - & 4.7 \\
\hline \multicolumn{4}{|l|}{$\begin{array}{l}\text { Patient's global evaluation } \\
\text { of efficacy }\end{array}$} \\
\hline Major improvement & - & - & 65.6 \\
\hline Minor improvement & - & - & 16.9 \\
\hline No change or worse & - & - & 12.7 \\
\hline Not done/not applicable & - & - & 6.4 \\
\hline
\end{tabular}

aMulticenter, open-label, non-comparative study at 36 centres across

Europe.

bPatient assessment.

cPhysician assessment.

into a second 6-month follow-up phase (ie, total of 12 months). All symptoms (pruritus, number and size of wheals) improved significantly $(P=.0001)$ compared with baseline from month 1 (the first postbaseline visit) onwards and remained significantly improved at 6 months (Figure). The percentage of patients with constant pruritus decreased from $23.9 \%$ at baseline to $4.8 \%$ after 6 months (Figure, A, a), while the percentage who had $\geq 16$ wheals decreased from $47.0 \%$ to $13.2 \%$ (Figure, $\mathrm{A}, \mathrm{b})$ and the percentage who had wheals $\geq 30 \mathrm{~mm}$ in size decreased from $28.7 \%$ to $7.2 \%$ (Figure, A, c) (all $P=.0001$ ). At 6 months, more than $70 \%$ of patients and physicians rated the overall efficacy of ebastine as optimal or good. Significant differences $(P=.0001)$ from baseline in all symptoms were also seen at 12 months (Figure, B a, b, c) in the subgroup that continued into the extension period.

The other long-term study evaluated the safety and efficacy of ebastine $10 \mathrm{mg}$ in 192 adults with chronic urticaria enrolled from 36 centers across Europe [81]. Some patients entered this open-label study after participating in the trial that compared ebastine with terfenadine and placebo [78], while others were enrolled de novo. Statistical comparisons with baseline were not performed, although there was a clear improvement in symptoms (including itching), the number of hours with symptoms, and wheal number and size during the 12-month treatment period (Tables 5 and 6). The percentage of patients with severe itching decreased from $22.4 \%$ at baseline to $<1 \%$ at 12 months, the mean number of hours spent with symptoms of urticaria decreased from 38 to 6 hours per week, the percentage of patients with wheals of $\geq 30 \mathrm{~mm}$ in diameter decreased from $14.6 \%$ to $2.8 \%$, and the percentage of patients with $\geq 16$ wheals decreased from $27.1 \%$ to $5.6 \%$. The overall evaluation of efficacy indicated that approximately $65 \%$ of both patients and physicians considered there had been a major improvement in symptoms during the study (Tables 5 and 6).

The EAACI/GA2LEN/EDF/WAO guidelines on urticaria suggest that in patients with an inadequate response to standard doses of second-generation $\mathrm{H}_{1}$-antihistamines, the dose can be increased by up to 4 times the standard recommended dose [20]. The approved dose for ebastine in patients with urticaria is 10 mg. A small noncomparative study found that ebastine was well tolerated and effective at higher doses in patients with chronic spontaneous urticaria (Table 5) [79]. Thirty patients were treated with ebastine for 4 weeks. The initial $10 \mathrm{mg}$ dose could be increased after the first and second weeks in those patients with an inadequate response to $20 \mathrm{mg}$ and then $40 \mathrm{mg}$ (administered as $10 \mathrm{mg}$ or $20 \mathrm{mg}$ twice daily). At the end of the first week, the dose was increased in 10 of 27 patients ( 3 patients were lost to follow-up). At the end of the second week the dose was increased again in 2 of these 10 patients. The overall mean urticaria activity score decreased from 4.6 at baseline to 2.2 after 1 week, 1.1 after 2 weeks, and $<1.0$ at 4 weeks. In addition, 17,8 , and 2 patients became symptomfree on doses of 10, 20, and $40 \mathrm{mg}$, respectively. One patient reported mild sedation (at a dose of $40 \mathrm{mg}$ ) [79].

Studies of ebastine in types of urticaria other than chronic idiopathic/spontaneous urticaria have generally used a dose of $20 \mathrm{mg}$ (Table 5). The results of 2 small, double-blind, crossover studies ( $n=22$ and $n=7)$ suggested that ebastine $20 \mathrm{mg}$ might be effective at preventing the symptoms of acquired cold urticaria [84] and dermographic urticaria [82], including wheals, burning, and itching. Recently, ebastine $20 \mathrm{mg}$ was found to have similar efficacy to levocetirizine $5 \mathrm{mg}$ and to be more effective than ebastine $10 \mathrm{mg}$ in the treatment of acute urticaria in patients aged $10-70$ years $(n=150)$ [82]. By week 4 of the study, complete relief of symptoms was achieved in $80 \%$ of patients taking ebastine $20 \mathrm{mg}, 70 \%$ of those taking levocetirizine, and $50 \%$ of those taking ebastine $10 \mathrm{mg}$. The mean Urticaria Activity Scores in these groups at week 4 were $1.08,1.98$, and 3.98 , respectively (Table 5).

\section{Safety and Tolerability}

Ebastine 10-20 mg was generally well tolerated in clinical trials of 1-4 weeks' duration in patients with allergic rhinitis or urticaria: the incidence of adverse events with ebastine was similar to that for placebo, and most events were mild 
or moderate in severity $[54,55,57,59-62,77]$. The incidence of adverse events with ebastine was similar to that for active comparators such as loratadine and cetirizine [58-60,64,65]. The most common adverse events with ebastine in placebocontrolled trials were headache $(7.9 \%)$, drowsiness $(3.0 \%)$, and dry mouth $(2.1 \%)$ [21].

Ebastine was found to have a favorable risk-benefit ratio with respect to sedation and had no clinically relevant adverse effects on cognitive or psychomotor functioning [45,85-90]. A more recent analysis of the central nervous system effects associated with second-generation $\mathrm{H}_{1}$-antihistamines calculated proportional impairment ratios for each drug compared with all the others (with higher values indicating greater impairment) and ranked ebastine as one of the lowest for impairment of objective measures of cognitive and psychomotor function (ratio 0, 95\% CI, 0-1.91) [91].

Ebastine had no clinically relevant adverse cardiac effects at recommended doses in clinical trials, although small increases in the QTc interval were seen when ebastine was coadministered with ketoconazole or erythromycin [37,92-94]. As a preventive measure, caution is recommended for some secondgeneration antihistamines such as ebastine or rupatadine in patients with known QTc interval prolongation or who use drugs that increase it. A recent case-control analysis of antihistamines using 7 population-based healthcare databases from 5 European countries (ARITMO project) found that ebastine was associated with an increased risk of ventricular tachyarrhythmia in 2 out of the 7 databases, one from Germany (GEPARD, 180 cases and 16986 controls: adjusted odds ratio [aOR], 3.3, 95\%CI, 1.1-10.8 vs no use of any antihistamine) and the other from The Netherlands (PHARMO, 538 cases and 52890 controls: aOR, 4.6; 95\%CI, 1.3-16.2). However, no such increased risk was found in the other 5 databases or in the overall pooled analysis involving a much larger number of cases/controls (2507/239 523) [95]. Moreover, ebastine was not prescribed extensively in the countries covered by the study, and only 8 cases and 680 controls were included in total. Pharmacovigilance data collected since ebastine was first introduced in 1989 have not resulted in any relevant change in the tolerability and safety texts of the approved summary of product characteristics after an estimated 65.5 million patients have received the original product.

Studies of 3-4 months' duration indicated that ebastine 10$20 \mathrm{mg}$ was well tolerated in the long term $[57,63,78]$. Data from 2 previously unpublished, open-label studies in which ebastine $10 \mathrm{mg}$ was administered to patients with chronic urticaria for up to 1 year confirmed that ebastine was well tolerated during long-term treatment $[80,81]$.

In the first of these studies, in which the main aim was to evaluate safety and tolerability over a 6-month period $(n=251)$, the percentage of patients reporting adverse events decreased over time, from $17.9 \%$ at 1 month to $7.2 \%$ at 6 months [80]. The most common adverse events reported at 1 month were drowsiness $(4.6 \%)$, headache $(3.7 \%)$, and gastralgia $(2.0 \%)$. The most common adverse events reported at 6 months were drowsiness $(2.0 \%)$, gastralgia $(1.7 \%)$, and increased appetite $(1.2 \%)$. At 6 months, $87.2 \%$ of physicians and $84.5 \%$ of patients considered the overall tolerability of ebastine to be "good" (options: good, average, poor, not done). Among 58 patients who continued for an additional 6 months (ie, total of
12 months), 8.6\% reported adverse events beyond 6 months, and $100 \%$ of physicians and patients reported overall tolerability as "good" at 12 months.

The second long-term study in chronic urticaria evaluated the safety and tolerability of ebastine in 192 patients over a 12-month period [81]. Adverse events were reported for $59.4 \%$ of patients during the study period. Most were mild or moderate in severity. The most frequent treatment-related adverse events were weight gain (7.3\%), increased appetite $(5.2 \%)$, headache $(4.7 \%)$, abdominal pain $(4.7 \%)$, dry mouth $(2.6 \%)$, and nervousness $(2.6 \%)$. At the end of the study, physicians judged the overall tolerability of ebastine as "good" for $87.3 \%$ of patients (options: good, fair, poor, not done).

\section{Conclusion}

Antihistamines are recommended by allergic rhinitis and urticaria guidelines $[1,19]$. Because of their favorable efficacy-to-safety ratio, second-generation $\mathrm{H}_{1}$-antihistamines are recommended as first-line therapy for patients with allergic rhinitis/rhinoconjunctivitis or urticaria $[1,20,94]$.

Ebastine is a once-daily, oral, second-generation $\mathrm{H}_{1-}$ antihistamine. The standard starting dose of $10 \mathrm{mg}$ can be increased to $20 \mathrm{mg}$ in patients with more severe or difficultto-control symptoms. The availability of 2 formulations in a number of countries (a standard tablet and a fast-dissolving tablet that disintegrates in the mouth) provides patients with different options to suit their daily lives and preferences. Ebastine has been demonstrated to be efficacious and well-tolerated in patients with allergic rhinitis or chronic urticaria in multiple clinical trials. The results of clinical trials published since the last in-depth review of ebastine support its efficacy and generally good tolerability when administered at recommended doses. In particular, new long-term data confirm its efficacy and tolerability for up to 1 year of treatment in patients with chronic urticaria. Recent findings also confirm that ebastine is one of the lowestrisk antihistamines in terms of cognitive and psychomotor effects. Ebastine was not associated with adverse cardiac effects in clinical trials. Finally, newer studies support previous evidence that in addition to its antihistamine effects, ebastine has modulating effects on the nonhistamine allergic inflammatory processes. This may help explain the beneficial effect of ebastine on nasal obstruction in some patients. No new tolerability or safety signals have emerged from worldwide use of the drug.

In conclusion, ebastine is an effective and well-tolerated second-generation $\mathrm{H}_{1}$-antihistamine for the treatment of symptoms in patients with allergic rhinitis or urticaria. Newer data support the findings of earlier clinical trials and further endorse the usefulness of ebastine in daily clinical practice.

\section{Acknowledgments}

Medical writing and editing assistance were provided by Content Ed Net and funded by Almirall S.A., Barcelona, Spain. 


\section{Funding}

The manuscript was funded by Almirall S.A., Barcelona, Spain.

\section{Conflicts of Interest}

The author reports having served as a consultant to FAES Farma, GlaxoSmithKline, LETI, Mundipharma, Novartis, Sanofi, and Thermo Fisher Scientific. He has also been paid lecture fees by FAES Farma, GlaxoSmithKline, LETI, Novartis, Sanofi, and Stallergenes and has received received grant support for research from ALK, Sanofi, and Thermo Fisher Scientific.

\section{References}

1. Bousquet J, Khaltaev N, CruzAA, Denburg J, Fokkens WJ, Togias A, et al. World Health Organization; GA(2)LEN; AllerGen. Allergic Rhinitis and its Impact on Asthma (ARIA) 2008 update (in collaboration with the World Health Organization, GA(2)LEN and AllerGen). Allergy. 2008;63 Suppl 86:8-160.

2. Maurer M, Weller K, Bindslev-Jensen C, Giménez-Arnau A, Bousquet PJ, Bousquet J, et al. Unmet clinical needs in chronic spontaneous urticaria. A GA2LEN task force report. Allergy. 2011;66:317-30.

3. Passali D, Cingi C, Staffa P, Passali F, Muluk NB, Bellussi ML. The International Study of the Allergic Rhinitis Survey: outcomes from 4 geographical regions. Asia Pac Allergy. 2018;8:e7.

4. Asher MI, Montefort S, Björkstén B, Lai CK, Strachan DP, Weiland SK, Williams H; ISAAC Phase Three Study Group. Worldwide time trends in the prevalence of symptoms of asthma, allergic rhinoconjunctivitis, and eczema in childhood: ISAAC Phases One and Three repeat multicountry crosssectional surveys. Lancet. 2006;368:733-43.

5. Katelaris $\mathrm{CH}$, Lee BW, Potter PC, Maspero JF, Cingi C, Lopatin $A$, et al. Prevalence and diversity of allergic rhinitis in regions of the world beyond Europe and North America. Clin Exp Allergy. 2012;42:186-207.

6. Wang XD, Zheng M, Lou HF, Wang CS, Zhang Y, Bo MY, et al. An increased prevalence of self-reported allergic rhinitis in major Chinese cities from 2005 to 2011. Allergy. 2016;71:1170-80.

7. Balp MM, Weller K, Carboni V, Chirilov A, Papavassilis C, Severin $T$, et al. Prevalence and clinical characteristics of chronic spontaneous urticaria in pediatric patients. Pediatr Allergy Immunol. 2018;29:630-6.

8. Zuberbier T, Balke M, Worm M, Edenharter G, Maurer M. Epidemiology of urticaria: a representative cross-sectional population survey. Clin Exp Dermatol. 2010;35:869-73.

9. Sánchez J, Zakzuk J, Cardona R. Prediction of the efficacy of antihistamines in chronic spontaneous urticaria based on initial suppression of the histamine-induced wheal. J Investig Allergol Clin Immunol. 2016;26:177-84.

10. Blaiss MS, Hammerby E, Robinson S, Kennedy-Martin T, Buchs S. The burden of allergic rhinitis and allergic rhinoconjunctivitis on adolescents: A literature review. Ann Allergy Asthma Immunol. 2018;121:43-52.e3.

11. Maspero J, Lee BW, Katelaris CH, Potter PC, Cingi C, Lopatin A, et al. Quality of life and control of allergic rhinitis in patients from regions beyond western Europe and the United States. Clin Exp Allergy. 2012;42:1684-96.
12. Maurer M, Abuzakouk M, Bérard F, Canonica W, Oude Elberink H, Giménez-Arnau A, et al. The burden of chronic spontaneous urticaria is substantial: Real-world evidence from ASSURECSU. Allergy. 2017;72:2005-16.

13. Storms W. Allergic rhinitis-induced nasal congestion: its impact on sleep quality. Prim Care Respir J. 2008;17:7-18.

14. Virchow JC, Kay S, Demoly P, Mullol J, Canonica W, Higgins V. Impact of ocular symptoms on quality of life (QoL), work productivity and resource utilisation in allergic rhinitis patients--an observational, cross sectional study in four countries in Europe. J Med Econ. 2011;14:305-14.

15. Colás C, Brosa M, Antón E, Montoro J, Navarro A, Dordal MT, et al.; Rhinoconjunctivitis Committee of the Spanish Society of Allergy and Clinical Immunology. Estimate of the total costs of allergic rhinitis in specialized care based on real-world data: the FERIN Study. Allergy. 2017;72:959-66.

16. Vandenplas O, Vinnikov D, Blanc PD, Agache I, Bachert C, Bewick $\mathrm{M}$, et al. Impact of rhinitis on work productivity: J Allergy Clin Immunol in practice. A Systematic Review. J Allergy Clin Immunol Pract. 2018;6:1274-86.

17. del Cuvillo A, Mullol J, Bartra J, Dávila I, Jáuregui I, Montoro J, et al. Comparative pharmacology of the $\mathrm{H} 1$ antihistamines. J Investig Allergol Clin Immunol. 2006;16 Suppl 1:3-12.

18. González-de-Olano D, Álvarez-Twose I. Mast cells as key players in allergy and inflammation. J Investig Allergol Clin Immunol. 2018;28:365-78.

19. Wise SK, Lin SY, Toskala E, Orlandi RR, Akdis CA, Alt JA, et al. International Consensus Statement on Allergy and Rhinology: Allergic Rhinitis. Int Forum Allergy Rhinol. 2018;8:108-35.

20. Zuberbier $T$, Aberer $W$, Asero R, Abdul Latiff AH, Baker $D$, Ballmer-Weber $\mathrm{B}$, et al. The EAACl/GA²LEN/EDF/WAO guideline for the definition, classification, diagnosis and management of urticaria. Allergy. 2018;73:1393-414.

21. Sastre J. Ebastine in allergic rhinitis and chronic idiopathic urticaria. Allergy. 2008;63 Suppl 89:1-20.

22. Barbanoj MJ, Antonijoan RM, García-Gea C, Morte A, Gich I, Gispert J, et al. A study comparing the inhibitory effects of single and repeated oral doses of ebastine and fexofenadine against histamine-induced skin reactivity. Int Arch Allergy Immunol. 2003;132:263-7.

23. Antonijoan RM, García-Gea C, Puntes M, Valle M, Esbri R, Fortea J, et al. A comparison of ebastine $10 \mathrm{mg}$ fast-dissolving tablet with oral desloratadine and placebo in inhibiting the cutaneous reaction to histamine in healthy adults. Clin Drug Investig. 2007;27:453-61.

24. Antonijoan R, García-Gea C, Puntes M, Pérez J, Esbrí R, Serra $C$, et al. Comparison of inhibition of cutaneous histamine reaction of ebastine fast-dissolving tablet $(20 \mathrm{mg})$ versus desloratadine capsule (5 mg): a randomized, double-blind, double-dummy, placebo-controlled, three-period crossover study in healthy, nonatopic adults. Clin Ther. 2007;29:814-22.

25. Frossard N, Benabdesselam O, Purohit A, Mounedji N, Pauli G. Activity of ebastine (10 and $20 \mathrm{mg}$ ) and cetirizine at 24 hours of a steady state treatment in the skin of healthy volunteers. Fundam Clin Pharmacol. 2000;14:409-13.

26. Gispert J, Antonijoan R, Barbanoj M, Gich I, Garcia E, Esbrí $R$, et al. Efficacy of ebastine, cetirizine, and loratadine in histamine cutaneous challenges. Ann Allergy Asthma Immunol. 2002;89:259-64. 
27. Nelson HS, Bucher B, Buchmeier A, Oppenheimer J, Garcia J. Suppression of the skin reaction to histamine by ebastine. Ann Allergy Asthma Immunol. 1995;74:442-7.

28. Vincent J, Liminana $R$, Meredith PA, Reid JL. The pharmacokinetics, antihistamine and concentrationeffect relationship of ebastine in healthy subjects. $\mathrm{Br} J$ Clin Pharmacol. 1988;26:497-502.

29. van Steekelenburg J, Clement PA, Beel MH. Comparison of five new antihistamines ( $\mathrm{H} 1$-receptor antagonists) in patients with allergic rhinitis using nasal provocation studies and skin tests. Allergy. 2002;57:346-50.

30. Frossard N, Vital-Durand D, Mounedji N, Valleteau A. Duration of the antihistaminic effect after discontinuation of ebastine. Allergy. 2001;56:553-7.

31. Frossard N, Melac M, Benabdesselam O, Pauli G. Consistency of the efficacy of cetirizine and ebastine on skin reactivity. Ann Allergy Asthma Immunol. 1998;80:61-5.

32. Wood-Baker R, Holgate ST. Dose-response relationship of the H1-histamine antagonist, ebastine, against histamine and methacholine-induced bronchoconstriction in patients with asthma. Agents Actions. 1990;30:284-6.

33. Campbell A, Michel FB, Bremard-Oury C, Crampette L, Bousquet J. Overview of allergic mechanisms. Ebastine has more than an antihistamine effect. Drugs. 1996;52 Suppl $1: 15-9$.

34. Horiguchi T, Tachikawa S, Kasahara J, Shiga M, Kondo R, Miyazaki J, et al. Effect of ebastine on serum eosinophil cationic protein levels in patients with bronchial asthma. Clin Drug Invest 1999; 17:435-40.

35. Ciprandi G, Cirillo I, Pistorio A, Di Gioacchino M, Fenoglio D. Ebastine increases IFN-gamma production in patients with persistent allergic rhinitis. J Biol Regul Homeost Agents. 2009:23:31-6.

36. De Luisi A, Mangialardi G, Ria R, Acuto G, Ribatti D, Vacca A. Anti-angiogenic activity of carebastine: a plausible mechanism affecting airway remodelling. Eur Respir J. 2009;34:958-66.

37. Chaikin P, Gillen MS, Malik M, Pentikis H, Rhodes GR, Roberts DJ. Co-administration of ketoconazole with $\mathrm{H} 1$-antagonists ebastine and loratadine in healthy subjects: pharmacokinetic and pharmacodynamic effects. Br J Clin Pharmacol. 2005;59:346-54.

38. Frank H Jr, Gillen M, Rohatagi SS, Lim J, George G; Ebastine Study Group. A double-blind, placebo-controlled study of the efficacy and safety of ebastine $20 \mathrm{mg}$ once daily given with and without food in the treatment of seasonal allergic rhinitis. J Clin Pharmacol. 2002;42:1097-104.

39. Hashizume T, Imaoka S, Mise M, Terauchi Y, Fujii T, Miyazaki H, et al. Involvement of CYP2J2 and CYP4F12 in the metabolism of ebastine in human intestinal microsomes. J Pharmacol Exp Ther. 2002;300:298-304.

40. Hashizume T, Mise M, Terauchi Y, O L, Fujii T, Miyazaki H, Inaba T. N-Dealkylation and hydroxylation of ebastine by human liver cytochrome P450. Drug Metab Dispos. 1998;26:566-71.

41. Huang MY, Argenti D, Wilson J, Garcia J, Heald D. Pharmacokinetics and electrocardiographic effect of ebastine in young versus elderly healthy subjects. Am J Ther. 1998;5:153-8.

42. Ebastine: Spanish Summary of Product Characteristics. February 2019.

43. Lasseter KC, Dilzer SC, Vargas R, Waldman S, Noveck RJ. Pharmacokinetics and safety of ebastine in patients with impaired hepatic function compared with healthy volunteers: a phase I open-label study. Clin Pharmacokinet. 2004;43:1219.

44. Liu KH, Kim MG, Lee DJ, Yoon YJ, Kim MJ, Shon JH, et al. Characterization of ebastine, hydroxyebastine, and carebastine metabolism by human liver microsomes and expressed cytochrome P450 enzymes: major roles for CYP2J2 and CYP3A. Drug Metab Dispos. 2006;34:1793-7.

45. Mattila MJ, Aranko K, Kuitunen T. Diazepam effects on the performance of healthy subjects are not enhanced by treatment with the antihistamine ebastine. Br J Clin Pharmacol. 1993;35:272-7.

46. Mattila MJ, Kuitunen T, Plétan Y. Lack of pharmacodynamic and pharmacokinetic interactions of the antihistamine ebastine with ethanol in healthy subjects. Eur J Clin Pharmacol. 1992:43:179-84.

47. Noveck RJ, Preston RA, Swan SK. Pharmacokinetics and safety of ebastine in healthy subjects and patients with renal impairment. Clin Pharmacokinet. 2007;46:525-34.

48. Rohatagi S, Gillen M, Aubeneau M, Jan C, Pandit B, Jensen $B K$, et al. Effect of age and gender on the pharmacokinetics of ebastine after single and repeated dosing in healthy subjects. Int J Clin Pharmacol Ther. 2001;39:126-34.

49. Shon JH, Yeo CW, Liu KH, Lee SS, Cha IJ, Shin JG. Itraconazole and rifampin alter significantly the disposition and antihistamine effect of ebastine and its metabolites in healthy participants. J Clin Pharmacol. 2010;50:195-204.

50. Van Rooij J, Schoemaker HC, Bruno R, Reinhoudt JF, Breimer $D D$, Cohen AF. Cimetidine does not influence the metabolism of the $\mathrm{H} 1$-receptor antagonist ebastine to its active metabolite carebastine. Br J Clin Pharmacol. 1993;35:661-3.

51. Pentikis HS, Huang MY, Dorr MB, Heald DL. The effect of food on the bioavailability of ebastine. Am J Ther. 1997;4:80-4.

52. Yamaguchi $T$, Hashizume $T$, Matsuda $M$, Sakashita M, Fujii $T$, Sekine $Y$, et al. Pharmacokinetics of the H1-receptor antagonist ebastine and its active metabolite carebastine in healthy subjects. Arzneimittelforschung. 1994;44:59-64.

53. Salvà M, Carreño B, Pintos M, Jansat JM, Rosales MJ, Megard Y. Phase I, single dose, open-label, randomized, crossover bioequivalence studies of ebastine $10 \mathrm{mg}$ and $20 \mathrm{mg}$ regular tablets vs. 10 and $20 \mathrm{mg}$ fast-dissolving tablets in healthy male volunteers. J InvestAllergol Clin Immunol 2004; 14(Suppl. 1):S5.

54. Ankier SI, Warrington SJ. A double-blind placebo-controlled study of the efficacy and tolerability of ebastine against hayfever in general practice patients. J Intern Med. 1989:226:453-8.

55. Peláez A. Clinical efficacy of ebastine in the treatment and prevention of seasonal allergic rhinitis. Drugs. 1996;52 Suppl 1:35-8.

56. de Molina M, Cadahia A, Cano L, Sanz A. Efficacy and tolerability of ebastine at two dose levels in the treatment of seasonal allergic rhinitis. Drug Invest. 1989;1:40-6.

57. Storms WW. Clinical studies of the efficacy and tolerability of ebastine 10 or $20 \mathrm{mg}$ once daily in the treatment of seasonal allergic rhinitis in the US. Drugs. 1996;52 Suppl 1:20-5.

58. Gehanno P, Bremard-Oury C, Zeisser P. Comparison of ebastine to cetirizine in seasonal allergic rhinitis in adults. Ann Allergy Asthma Immunol. 1996;76:507-12. 
59. Hampel F Jr, Howland W 3rd, Van Bavel J, Ratner P. A randomized, double-blind, placebo-controlled study comparing the efficacy and safety of ebastine $(20 \mathrm{mg}$ and $10 \mathrm{mg}$ ) to loratadine $10 \mathrm{mg}$ once daily in the treatment of seasonal allergic rhinitis. J Investig Allergol Clin Immunol. 2004; 14:56-63.

60. Ratner PH, Lim JC, Georges GC. Comparison of once-daily ebastine $20 \mathrm{mg}$, ebastine $10 \mathrm{mg}$, loratadine $10 \mathrm{mg}$, and placebo in the treatment of seasonal allergic rhinitis. The Ebastine Study Group. J Allergy Clin Immunol. 2000;105:1101-7.

61. Ratner P, Hampel F Jr, Van Bavel J, Howland W 3rd. Efficacy and safety of ebastine $20 \mathrm{mg}$ compared to loratadine $10 \mathrm{mg}$ once daily in the treatment of seasonal allergic rhinitis: a randomized, double-blind, placebo-controlled study. Int Arch Allergy Immunol. 2004;133:371-9.

62. Picado Vallés C, Cadahia García A, Cisteró Bahima A, Cano Cantudo L, Sanz Amaro A, Zayas Sanza JM. Ebastine in perennial allergic rhinitis. Ann Allergy. 1991;67:615-8.

63. Bousquet J, Gaudaño EM, Palma Carlos AG, Staudinger H. A 12-week, placebo-controlled study of the efficacy and safety of ebastine, 10 and $20 \mathrm{mg}$ once daily, in the treatment of perennial allergic rhinitis. Multicentre Study Group. Allergy. 1999; 54:562-8.

64. Murris-Espin M, Melac M, Charpentier JC, Didier A. Comparison of efficacy and safety of cetirizine and ebastine in patients with perennial allergic rhinitis. Ann Allergy Asthma Immunol. 1998;80:399-403.

65. Davies RJ; European Multicentre Study Group. Efficacy and tolerability comparison of ebastine 10 and $20 \mathrm{mg}$ with loratadine 10mg: a double-blind, randomised study in patients with perennial allergic rhinitis. Clin Drug Investig. 1998; 16:413-20.

66. Ratner P, Falqués $M$, Chuecos F, Esbrí R, Gispert J, Peris F, et al. Meta-analysis of the efficacy of ebastine $20 \mathrm{mg}$ compared to loratadine $10 \mathrm{mg}$ and placebo in the symptomatic treatment of seasonal allergic rhinitis. Int Arch Allergy Immunol. 2005;138:312-8.

67. Eifan AO, Durham SR. Pathogenesis of rhinitis. Clin Exp Allergy. 2016:46:1139-51.

68. Okubo K, Kurono Y, Ichimura K, Enomoto T, Okamoto $Y$, Kawauchi $\mathrm{H}$, et al.; Japanese Society of Allergology. Japanese guidelines for allergic rhinitis 2017. Allergol Int. 2017;66:20519.

69. Valero A, Navarro AM, Del Cuvillo A, Alobid I, Benito JR, Colás $C$ et al. Position paper on nasal obstruction: evaluation and treatment. J Investig Allergol Clin Immunol. 2018;28:67-90.

70. Ratner P, Hampel F Jr, Gispert J. Efficacy of ebastine in the control of nasal congestion associated with allergic rhinitis. Methods Find Exp Clin Pharmacol. 2003;25:111-5.

71. Ciprandi G, Cirillo I, Mora F, La Rosa M. Ebastine improves nasal symptoms and airflow and affects response to decongestion test in patients with persistent allergic rhinitis: a pilot study. Allergy Asthma Proc. 2007;28:578-81.

72. Ciprandi G. Clinical utility and patient adherence with ebastine for allergic rhinitis. Patient Prefer Adherence. 2010;4:389-95.

73. Roger A, Fortea J, Mora S, Artés M. Ebastine fast-dissolving tablets versus regular tablets: acceptability and preference in patients with allergic rhinitis. Expert Rev Clin Pharmacol. 2008;1:381-9.
74. Roger A, Fortea J, Mora S, Artés M. Patient assessment of onset of action and overall satisfaction with ebastine fast-dissolving tablets in allergic rhinitis. Expert Rev Pharmacoecon Outcomes Res. 2008;8:337-42.

75. Roger Reig A, Plazas Fernández MJ, Galván Cervera J, Heras Navarro J, Artés Ferragud M, Gabarrón Hortal E. Acceptance survey of a fast dissolving tablet pharmaceutical formulation in allergic patients. Satisfaction and expectancies. Allergol Immunopathol (Madr). 2006;34:107-12.

76. Roger A, Fortea J, José Plazas M, Mora S, Artés M. Assessment of patient satisfaction with ebastine fast-dissolving tablets in patients suffering from allergic rhinitis. Therapy. 2009;6:40715.

77. Peyri J, Vidal J, Marrón J, Fonseca E, Suárez E, Ledo A, et al. Ebastine in chronic urticaria: a double-blind placebocontrolled study. J Dermatol Treat. 1991;2:51-3.

78. Kalis B. Double-blind multicentre comparative study of ebastine, terfenadine and placebo in the treatment of chronic idiopathic urticaria in adults. Drugs. 1996;52 Suppl 1:30-4.

79. Godse KV. Ebastine in chronic spontaneous urticaria in higher doses. Indian J Dermatol. 2011;56:597-8.

80. Rhône-Poulenc Rorer. Open long-term study of the safety, tolerability of ebastine (LAS W 0-90) in patients with chronic urticaria (study CLIN 2.12). Antony Cedex (France): RhônePoulenc Rorer; 1988 Dec. Report no.: 69 (PART IV.B.1).

81. Rhône-Poulenc Rorer. A long-term (one-year) safety and efficacy phase III study of ebastine $(10 \mathrm{mg})$ in the treatment of chronic urticaria in adult patients (study EBA 020). Antony Cedex (France): Rhône-Poulenc Rorer; 1997 Jul. Report no.: RP-64305-020.

82. Goyal V, Gupta A, Gupta O, Lal D, Gill M. Comparative efficacy and safety of ebastine $20 \mathrm{mg}$, ebastine $10 \mathrm{mg}$ and levocetirizine $5 \mathrm{mg}$ in acute urticaria. J Clin Diagn Res. 2017; 11:WC06-9.

83. Magerl M, Schmolke J, Metz M, Zuberbier T, Siebenhaar $F$, Maurer M. Prevention of signs and symptoms of dermographic urticaria by single-dose ebastine $20 \mathrm{mg}$. Clin Exp Dermatol. 2009;34:e137-40.

84. Magerl M, Schmolke J, Siebenhaar F, Zuberbier T, Metz M, Maurer M. Acquired cold urticaria symptoms can be safely prevented by ebastine. Allergy. 2007;62:1465-8.

85. Hindmarch I, Shamsi Z. Antihistamines: models to assess sedative properties, assessment of sedation, safety and other side-effects. Clin Exp Allergy. 1999;29 Suppl 3:133-42.

86. Vincent J, Sumner DJ, Reid JL. Ebastine: the effect of a new antihistamine on psychomotor performance and autonomic responses in healthy subjects. Br J Clin Pharmacol. 1988;26:503-8.

87. O'Hanlon JF, Ramaekers JG. Antihistamine effects on actual driving performance in a standard test: a summary of Dutch experience, 1989-94. Allergy. 1995;50:234-42.

88. Hindmarch I, Shamsi Z. The effects of single and repeated administration of ebastine on cognition and psychomotor performance in comparison to triprolidine and placebo in healthy volunteers. Curr Med Res Opin. 2001;17:273-81.

89. Hopes $H$, Meuret $G H$, Ungethüm W, Leopold $G$, Wiemann $H$. Placebo controlled comparison of acute effects of ebastine and clemastine on performance and EEG. Eur J Clin Pharmacol. 1992;42:55-9. 
90. Brookhuis KA, De Vries G, De Waard D. Acute and subchronic effects of the $\mathrm{H} 1$-histamine receptor antagonist ebastine in 10, 20 and $30 \mathrm{mg}$ dose, and triprolidine $10 \mathrm{mg}$ on car driving performance. Br J Clin Pharmacol. 1993;36:67-70.

91. Isomura $T$, Kono $T$, Hindmarch I, Kikuchi N, Murakami $A$, Inuzuka $K$, et al. Central nervous system effects of the secondgeneration antihistamines marketed in Japan--review of inter-drug differences using the proportional impairment ratio (PIR)-. PLoS One. 2014;9:e114336.

92. Gillen MS, Miller B, Chaikin P, Morganroth J. Effects of supratherapeutic doses of ebastine and terfenadine on the QT interval. Br J Clin Pharmacol. 2001;52:201-4.

93. Moss AJ, Chaikin P, Garcia JD, Gillen M, Roberts DJ, Morganroth J. A review of the cardiac systemic side-effects of antihistamines: ebastine. Clin Exp Allergy. 1999;29 Suppl 3:200-5.

94. Rico S, Antonijoan R, Barbanoj M. Ebastine in the light of CONGA recommendations for the development of third- generation antihistamines. J Asthma Allergy. 2009;2:7392.

95. Poluzzi E, Diemberger I, De Ridder M, Koci A, Clo M, Oteri $A$, et al. Use of antihistamines and risk of ventricular tachyarrhythmia: a nested case-control study in five European countries from the ARITMO project. Eur J Clin Pharmacol. 2017;73:1499-510.

\section{- Joaquín Sastre}
Allergy Service
Fundación Jiménez Díaz
Av Reyes Católicos, 2
28040 Madrid, Spain.
E-mail: jsastre@fjd.es 